\title{
CANOPY STRUCTURE AND TILLERING OF PIATÃ AND MARANDU GRASSES UNDER TWO GRAZING INTENSITIES WITH SHEEP
}

\author{
ESTRUTURA DO DOSSEL E PERFILHAMENTO DOS CAPINS-PIATÃ E MARANDU \\ SOB INTENSIDADES DE PASTEJO COM OVINOS
}

\section{Carla Lailane Dias de LIMA ${ }^{1}$; Gelson dos Santos DIFANTE ${ }^{1^{*}}$; Kelen Cristina BASSO ${ }^{2}$, João Virgínio EMERENCIANO NETO ${ }^{3}$; Denise Baptaglin MONTAGNER ${ }^{4}$; Rayssa Iris Galvão VASCONCELOS ${ }^{1}$; Thiago Felipe de Medeiros TRINDADE ${ }^{1}$; Emmanuel Lievio de Lima VERAS ${ }^{1}$}

1. Programa de Pós-Graduação em Produção Animal, Universidade Federal do Rio Grande do Norte, Macaíba, RN, Brasil. *gdifante@ufrnet.br; 2. Universidade Federal de Santa Catarina, Curitibanos, SC, Brasil; 3. Universidade Federal do Vale do São Francisco, Petrolina, PE, Brasil; 4. Empresa Brasileira de Pesquisa Agropecuária, EMBRAPA Gado de Corte, Campo Grande, MS, Brasil.

\begin{abstract}
This study aimed to evaluate productive and structural parameters of Piatã and Marandu cultivars submitted to two grazing intensities. The experimental design was in randomized blocks with treatments in a $2 \times 2$ factorial arrangement (Marandu and Piatã palisadegrass x 25 and $30 \mathrm{~cm}$ residual heights). Intermittent stocking grazing method was used. Non-defined breed sheep were used as defoliation agents. Interaction between cultivars and height was not significant for any of the variables. In pastures managed at $25 \mathrm{~cm}$ post-grazing, a greater regrowth period was observed. Forage mass was on average $27 \%$ higher in Marandu palisadegrass in relation to Piatã palisadegrass, regardless of height. Dead material accumulation was higher in the Marandu cultivar. There was no difference in mass between the cultivars and heights for leaf blade or stem before and after grazing. The highest population density of tillers was observed in pastures lowered to $25 \mathrm{~cm}$ post-grazing height, with no difference between cultivars. In the third generation the appearance of tillers was higher in pastures managed at $25 \mathrm{~cm}$. Post-grazing heights of 25 and $30 \mathrm{~cm}$ do not change pasture structure in Piatã and Marandu cultivars in pre-grazing; however, it is possible to obtain a shorter regrowth period if managed at $30 \mathrm{~cm}$.
\end{abstract}

KEYWORDS: Brachiaria brizantha. Forage mass. Pasture management. Semiarid. Tillers.

\section{INTRODUCTION}

Production potential of a forage grass is genetically determined, however forage production is influenced by environment-soil-plant-animal interaction (DA SILVA; PEDREIRA, 1997; SALES et al., 2012). Genetic enhancement of forage grasses has made great strides through the launch of new cultivars and also the selection of hybrids, but it is necessary to apply pasture management and grazing practices in order to indicate specific recommendations for the use of each animal species and region of the country, thus ensuring that the productive potential of the forage plant is reached (JANK et al., 2012; PENATI et al., 2014).

Productivity of forage grasses depends on the continuous emission of leaves and tillers, an important process for the restoration of the leaf area after grazing or cropping that ensures continuity to the forage (GOMIDE; GOMIDE, 2000). Thus, barriers of animal production in pastures can be resolved, partly with management practices that increase the usage efficiency of the produced forage. Hence, morphophysiological knowledge of the plant is of fundamental importance for better adaptation of the employed management practices. Defoliation requires adequate monitoring based on information that ensures an optimal balance between growth processes, senescence and consumption in order to allow high yield of good quality forage (HODGSON, 1990).

In general, Brazilian pastures are formed by tropical grasses. The optimum temperature for the development of these species is around $30-35^{\circ} \mathrm{C}$ (AZEVEDO JUNIOR et al., 2012). Thus, it appears that the major limiting factor for forage production in the northeast region is water deficit. However, studies are being conducted to evaluate different species and cultivars, and to identify forages adapted to these conditions in order to improve the zootechnical indexes of the region.

The objectives of this study were to evaluate the canopy structure and forage production, density and population dynamics of tillers in Marandu and Piatã palisadegrass submitted to two grazing intensities under intermittent stock grazing in northeastern Brazil. 


\section{MATERIAL AND METHODS}

The experiment was conducted in the area of the Study Group on Forage (GEFOR, an Academic Unit Specialized in Agricultural Sciences) at the Federal University of Rio Grande do Norte, UFRN, in Macaíba, RN, Brazil. The experimental area is located at $5^{\circ} 53^{\prime} 35.12^{\prime \prime}$ South latitude and $35^{\circ} 21^{\prime} 47.03^{\prime}$ West longitude and 11 meters above sea level.
LIMA, C. L. D. et al.

The climate is sub-humid dry according to the Thornthwaite (1948) climatic classification, with water surplus from May to August. The average historic annual rainfall is $1048 \mathrm{~mm}$, and the annual evapotranspiration potential cumulative average is $1472 \mathrm{~mm}$. The evaluation period was from March to October 2012, with average monthly rainfall of 71 mm (Figure 1).

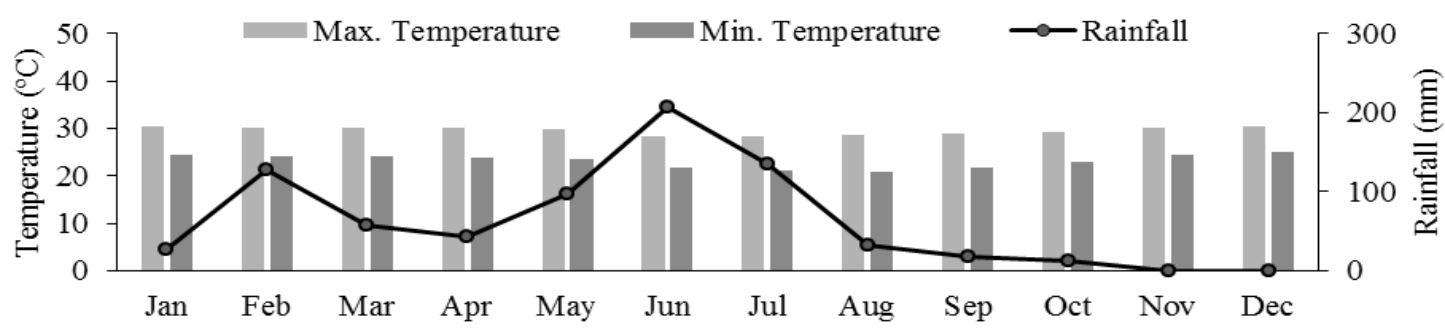

Figure 1. Average monthly rainfall and temperatures of the experimental area in 2012

The soil of the area is classified as Tipic Quartzipsamment (EMBRAPA, 2006). Soil analyzes were performed on the profiles of $0-20 \mathrm{~cm}$ and $20-40 \mathrm{~cm}$ at the beginning of the experiment (Table 1), and based on the results, $80 \mathrm{~kg} \mathrm{ha}^{-1} \mathrm{P}_{2} \mathrm{O}_{5}$ (super simple phosphate) and $50 \mathrm{~kg} \mathrm{ha}^{-1} \mathrm{~K}_{2} \mathrm{O}$ (potassium chloride) were applied in order to increase the base saturation by $60 \%$, the phosphorus content to between 8 and $12 \mathrm{mg} \mathrm{dm}^{-3}\left(\mathrm{P}-\mathrm{Mehlich}^{1}\right)$, and potassium content to between 80 and $100 \mathrm{mg}$ $\mathrm{dm}^{-3}$. During the trial period, a topdressing was applied with $42 \mathrm{~kg} \mathrm{ha}^{-1}$ nitrogen in the form of ammonium sulfate.

Table 1. Soil chemical properties of the experimental field

\begin{tabular}{ccccccccccc}
\hline $\begin{array}{c}\text { Layer } \\
(\mathrm{cm})\end{array}$ & $\mathrm{P}$ & $\begin{array}{c}\mathrm{K} \\
-----\end{array}$ & $\mathrm{ma} \mathrm{mm}^{-3}$ & $\mathrm{Na}$ & $\mathrm{Ca}$ & $\mathrm{Mg}$ & $\begin{array}{c}\mathrm{Al} \\
----\end{array}$ & $\mathrm{H}+\mathrm{Al}$ & $\mathrm{CEC}$ & $\mathrm{V}(\%)$ \\
\hline $0-20$ & 2.0 & 41.0 & 9.0 & 6.6 & 1.1 & 0.2 & 0.0 & 1.1 & 25.1 & 56.1 \\
$20-40$ & 1.0 & 22.0 & 9.0 & 6.3 & 0.5 & 0.1 & 0.0 & 0.6 & 12.6 & 52.2 \\
\hline
\end{tabular}

CEC, cation exchange capacity; $\mathrm{V}$, percentage of base saturation

The pastures were established in June 2010, with the conventional system of planting in rows with distribution of seeds and fertilizer $\left(\mathrm{P}_{2} \mathrm{O}_{5}\right)$. The experimental area was kept permanently free of weeds, and ants were controlled throughout the evaluation period. The experimental area of 2.88 ha was split into 2 lots of 1.44 ha with four modules of 0.36 ha for each treatment, subdivided into six paddocks of equal area (0.06 ha).

The grazing method employed was intermittent stock grazing, with the grazing interval being determined by the time that the pasture took to reach $45 \mathrm{~cm}$ in height (input goal) and terminated when post-grazing residual height goals were reached $(25$ or $30 \mathrm{~cm})$. Non-defined breed sheep with average live weight of $26.4 \pm 3.2 \mathrm{~kg}$ were used as defoliation agents, and were kept on pasture from 8 a.m. until 5 p.m.
The average height of the grass was determined using a one meter ruler with centimeter graduation. Forty readings per paddock were taken at representative points, and the average height of the curvature of the leaves around the ruler was considered.

The forage mass at the pre- and post-grazing conditions were estimated in the four paddocks of each module by cutting all the material at a height of $0.2 \mathrm{~m}$ of soil within six representative frames $(0.5$ $\mathrm{m}^{2}$ ). The collected samples were identified and weighed to obtain green weight. Two sub-samples were taken; one for determining the total dry matter, and another for determining the percentage of each morphological component in forage mass, being leaf blade, stem (stem + sheath) and dead material. Both were dried off by forced ventilation in an oven at $55^{\circ} \mathrm{C}$ for 72 hours to determine the dry weight. The 
forage volume density was calculated by dividing the forage dry mass per hectare by the canopy height in centimeters ( $\left.\mathrm{kg} \mathrm{ha}^{-1} . \mathrm{cm} \mathrm{DM}\right)$.

Tiller population density (TPD) was obtained by the total count of basal tillers contained in a framework of $0.25 \mathrm{~m}^{2}(0.5 \times 0.5 \mathrm{~m})$, randomly cast twice per plot. Tiller counting was performed after each cut, and all data were converted to tillers $\mathrm{m}^{-2}$.

Evaluation of tiller population dynamics was always performed after the cuts. Three frames made of galvanized steel wire were used, measuring $0.0625 \mathrm{~m}^{2}(0.25 \times 0.25 \mathrm{~m})$ and fixed to the ground with metal staples in representative sites of each installment at the beginning of the evaluations. In the first evaluation, all existing tillers within each square were marked with colored wire. All existing marked tillers were counted again at every new assessment, the new tillers were marked with a different color from previous markings, and the wires of dead tillers were counted and collected. Tillers which had gone missing and those that were dry or in an advanced stage of senescence were considered dead.

The experimental design was randomized blocks with treatments in a 2 x 2 factorial arrangement (cultivar $x$ residual heights). Data were submitted to analysis of variance and mean comparisons between cultivars, and Fisher's F-test $(\alpha=0.05)$ was used among the heights, as the interaction between factors was not significant $(P>0.05)$. The experimental design was based on the following model: $Y_{i j k l}=\mu+C_{i}+A_{j}+\mathrm{CA}_{i j}+B_{k}+$ $\beta_{\mathrm{ijk}}$, where: $\mu$, overall average effect; $C_{i}$, effect of cultivar i, I = Piatã and Marandu; $\mathrm{A}_{\mathrm{j}}$, effect of height $\mathrm{j}, \mathrm{j}=25$ and $30 \mathrm{~cm}$; $\mathrm{CA}_{\mathrm{ij}}$, effect of the interaction between the cultivar $\mathrm{i}$ and height $\mathrm{j} ; \mathrm{B}_{\mathrm{k}}$, effect of block $\mathrm{k}, \mathrm{k}=1$ and $2 ; \beta_{\mathrm{ijk}}$, random error associated with cultivar $\mathrm{i}$, in the height $\mathrm{j}$, in block $\mathrm{k}$, repetition 1 .

\section{RESULTS AND DISCUSSION}

No interaction between any of the sources of variation (cultivar, post-grazing height and grazing cycle) was observed for any of the evaluated variables $(P>0.05)$. The occupation period did not differ between the sources of variation, with an average duration of approximately 14 days. In this condition the animals probably grazed on the pasture regrowth, which if prolonged could compromise its longevity due to the reduced stock of the plants' organic reserves.

A longer period of regrowth $(P<0.05)$ was required for the sward to reach the pre-grazing height of $45 \mathrm{~cm}$ (Table 2) in pastures managed at 25 $\mathrm{cm}$ post-grazing heights without significant differences among cultivars. As stem elongation is the main factor responsible for the increase in canopy height (CASAGRANDE et al., 2010), postgrazing heights possibly did not modify stem elongation rates, and thus the regrowth time was a result of a higher required height.

Table 2. Occupation and regrowth periods, forage mass and morphological components in pre-grazing Brachiaria brizantha pastures under post-grazing heights

\begin{tabular}{|c|c|c|c|c|c|}
\hline \multirow{2}{*}{ Variable } & \multicolumn{2}{|c|}{----- Cultivar----- } & \multicolumn{2}{|c|}{------Height------ } & \multirow{2}{*}{$\mathrm{CV}(\%)$} \\
\hline & Piatã & Marandu & $25 \mathrm{~cm}$ & $30 \mathrm{~cm}$ & \\
\hline Occupation period (day) & $13.5 \mathrm{a}$ & $14.00 \mathrm{a}$ & $12.5 \mathrm{a}$ & $15.0 \mathrm{a}$ & 14.5 \\
\hline Regrowth period (day) & $81.0 \mathrm{a}$ & $72.5 \mathrm{a}$ & $86.0 \mathrm{a}$ & $67.5 b$ & 21.6 \\
\hline Forage mass $\left(\mathrm{kg} \mathrm{ha}^{-1} \mathrm{DM}\right)$ & $3676.9 \mathrm{~b}$ & $5096.2 \mathrm{a}$ & $4247.8 \mathrm{a}$ & $4539.9 \mathrm{a}$ & 38,0 \\
\hline Leaf blade percentage (\%) & $39.0 \mathrm{a}$ & $29.7 \mathrm{a}$ & $35.6 \mathrm{a}$ & $33.0 \mathrm{a}$ & 38,4 \\
\hline Leaf blade mass $\left(\mathrm{kg} \mathrm{ha}^{-1} \mathrm{DM}\right)$ & $1602.9 \mathrm{a}$ & $1512.0 \mathrm{a}$ & $1539.6 \mathrm{a}$ & $1570.4 \mathrm{a}$ & 10.4 \\
\hline Stem percentage $(\%)$ & $33.2 \mathrm{a}$ & $23.3 b$ & $27.5 \mathrm{a}$ & $28.6 \mathrm{a}$ & 20.3 \\
\hline Stem mass $\left(\mathrm{kg} \mathrm{ha}^{-1} \mathrm{DM}\right)$ & $1219.7 \mathrm{a}$ & $1266.1 \mathrm{a}$ & $1210.9 \mathrm{a}$ & $1271.3 \mathrm{a}$ & 24.7 \\
\hline Dead material percentage (\%) & $26.3 b$ & $46.9 \mathrm{a}$ & $36.8 \mathrm{a}$ & $37.0 \mathrm{a}$ & 26.7 \\
\hline Dead material mass $\left(\mathrm{kg} \mathrm{ha}^{-1} \mathrm{DM}\right)$ & $871.7 \mathrm{~b}$ & $2323.9 \mathrm{a}$ & $1495.3 \mathrm{a}$ & $1721.3 \mathrm{a}$ & 14.7 \\
\hline
\end{tabular}

Means followed by different letters differ by Fischer test $(P<0.05)$.

Pre-grazing forage mass differed between the cultivars, with Marandu palisadegrass obtaining an average of $37.5 \%$ more forage mass than Piatã palisadegrass (Table 2). Emerenciano Neto et al.
(2013) observed higher forage density in Marandu palisadegrass when compared to Piatã; this fact shows that pastures managed at the same canopy height may have different masses, and in this case 
Marandu palisadegrass was more productive than Piatã palisadegrass. The same authors found no difference between Piatã and Marandu cultivars regarding forage, leaf blade and stem production when using pre-grazing goals of $50 \mathrm{~cm}$ and postgrazing goals of $25 \mathrm{~cm}$ sward height.

Leaf blade and stem mass in the pre-grazing were neither influenced by the cultivars nor by net heights $(P>0.05)$. Dead material mass (DMM) only differed among cultivars, with the highest (mass) observed in Marandu palisadegrass pastures $(P<0.05)$. This result may be associated with a shorter life span of the leaf of this cultivar (SILVEIRA et al., 2010). Thus, the senescence process is more evident in the forage mass. The higher forage mass observed in Marandu palisadegrass does not represent an advantage compared to Piatã palisadegrass, considering that only the dead material is responsible for this difference. Pastures with a high percentage of dead material hinder the capacity of forage capture by the animals, affect the voluntary intake of grazing animals, and can compromise the efficiency ratios in the use of produced forage (CASAGRANDE et al., 2010; DIFANTE et al., 2011).
Morphological composition of pastures was affected by cultivar $(P<0.05)$, but it was without effect on the percentage of leaf blades. The percentage of stem and dead material were inverse with the lower percentage of stem and the higher percentage of dead material being in Marandu palisadegrass, with the opposite behavior in Piatã palisadegrass. Euclides et al. (2008) point out that the main differences in the canopy structure of these grasses are stem accumulation, which may cause a reduction in the leaf blade:stem ratio in Piatã in the rainy season, and suggest that grazing management should be differentiated for these cultivars.

In post-grazing, the largest masses of forage were observed in Marandu palisadegrass $(P<0.05)$, regardless of height, and for the post-grazing height of $30 \mathrm{~cm}(P<0.05)$, regardless of the cultivar. The residual mass of Marandu palisadegrass is the result of higher forage mass and dead material in pregrazing, as the stocking rate was the same for all the pastures, while the lowest mass in pastures managed at $25 \mathrm{~cm}$ was the result of the greater imposed grazing intensity.

Table 3. Forage mass and morphological components in the post-grazing of Brachiaria brizantha pastures under post-grazing canopy heights

\begin{tabular}{|c|c|c|c|c|c|}
\hline \multirow{2}{*}{ Variable } & \multicolumn{2}{|c|}{----- Cultivar----- } & \multicolumn{2}{|c|}{------ Height ------ } & \multirow{2}{*}{$\mathrm{CV}(\%)$} \\
\hline & Piatã & Marandu & $25 \mathrm{~cm}$ & $30 \mathrm{~cm}$ & \\
\hline Forage mass $\left(\mathrm{kg} \mathrm{ha}^{-1} \mathrm{DM}\right)$ & $2441.2 b$ & $3022.7 \mathrm{a}$ & $2369.1 \mathrm{~b}$ & $2976.9 a$ & 21.5 \\
\hline Leaf blade percentage $(\%)$ & $0.9 \mathrm{a}$ & $1.8 \mathrm{a}$ & $1.6 \mathrm{a}$ & $1.2 \mathrm{a}$ & 36.4 \\
\hline Leaf blade mass $\left(\mathrm{kg} \mathrm{ha}^{-1} \mathrm{DM}\right)$ & $30.3 \mathrm{a}$ & $50.1 \mathrm{a}$ & $36.1 \mathrm{a}$ & $42.7 \mathrm{a}$ & 27.3 \\
\hline Stem percentage $(\%)$ & $43.1 \mathrm{a}$ & $28.2 b$ & $34.4 \mathrm{a}$ & $36.9 \mathrm{a}$ & 17.4 \\
\hline Stem mass $\left(\mathrm{kg} \mathrm{ha}^{-1} \mathrm{DM}\right)$ & $1082.8 \mathrm{a}$ & $908.0 \mathrm{a}$ & $868.8 \mathrm{a}$ & $1088.7 \mathrm{a}$ & 28.9 \\
\hline Dead material percentage $(\%)$ & $56.1 \mathrm{~b}$ & $69.9 \mathrm{a}$ & $64.1 \mathrm{a}$ & $61.9 \mathrm{a}$ & 18.8 \\
\hline Dead material mass $\left(\mathrm{kg} \mathrm{ha}^{-1} \mathrm{DM}\right)$ & $1701.4 \mathrm{a}$ & $2057.9 \mathrm{a}$ & $1900.6 \mathrm{a}$ & $1857.4 \mathrm{a}$ & 25.4 \\
\hline
\end{tabular}

Means followed by different letters differ by Fischer test $(P<0.05)$.

Masses and percentage of leaf blades in the post-grazing did not differ between the sources of variation $(P>0.05)$. The amount of leaf blades in the post-grazing can be considered low, directly influencing the pasture recovery speed and consequently the regrowth period, since a large removal of leaf tissue dramatically reduces the photosynthetic rate in plants (ALEXANDRINO et al., 2008). When the animal is able to consume leaves, it seeks them out, even when the availability in the pasture is small and it needs to spend more time searching for them (BREMM et al., 2008). Thus, the grazing pressure used justifies the low availability of this component in the post-grazing.
There was no significant difference in the masses of stem and dead material in the postgrazing among cultivars $(P>0.05)$ and among postgrazing heights $(P>0.05)$. Emerenciano Neto et al. (2013) also found no difference in stem mass in the residue between Piatã and Marandu cultivars managed at $50 \mathrm{~cm}$ in pre-grazing; the authors found values exceeding $1000 \mathrm{~kg} \mathrm{ha}^{-1} \mathrm{DM}$ and attribute this result to excessive stem elongation to reach the determined height. The same behavior was observed in this experiment even when establishing a $45 \mathrm{~cm}$ goal for pre-grazing heights.

Stem and dead material percentages in the forage mass in post-grazing only differed among 
cultivars $(P>0.05)$, where Marandu palisadegrass obtained the highest dead material percentages and Piatã palisadegrass the higher stem percentages. The highest forage mass in Marandu palisadegrass provided greater shading in the lower canopy layers, resulting in lower photosynthetic rates of the leaves in these layers. The starting height is reflected in high loss of harvest efficiency of the produced forage, as it provided greater accumulation of dead material. Several authors have stressed the importance of stem and dead material modifying the canopy structure, and consequently animal performance (REGO et al., 2006; EUCLIDES et al., 2008).

Forage accumulation rates differed only among cultivars $(P<0.05)$, where the highest rates were observed in Marandu palisadegrass pastures. This outcome was the result of larger stem and dead material accumulation rates obtained by this cultivar, as the leaf blade accumulation rate was not affected by sources of variation $(P>0.05)$.

Table 4. Forage accumulation rates, morphological components, and tillering population density in Brachiaria brizantha pastures under post-grazing canopy heights

\begin{tabular}{lccccc}
\hline \multicolumn{1}{c}{ Variable } & \multicolumn{2}{c}{--- Cultivar---- } & \multicolumn{2}{c}{---- Height ----- } & CV \\
& Piatã & Marandu & $25 \mathrm{~cm}$ & $30 \mathrm{~cm}$ & $(\%)$ \\
\hline Forage accumulation rate $\left(\mathrm{kg} \mathrm{ha}^{-1}\right.$.day DM) & $15.3 \mathrm{~b}$ & $28.6 \mathrm{a}$ & $21.8 \mathrm{a}$ & $23.2 \mathrm{a}$ & 34,8 \\
Leaf blade accumulation rate $\left(\mathrm{kg} \mathrm{ha}^{-1}\right.$.day DM) & $19.4 \mathrm{a}$ & $20.2 \mathrm{a}$ & $17.5 \mathrm{a}$ & $22.6 \mathrm{a}$ & 25.7 \\
Stem accumulation rate $\left(\mathrm{kg} \mathrm{ha}^{-1}\right.$.day DM) & $1.7 \mathrm{~b}$ & $4.9 \mathrm{a}$ & $4.0 \mathrm{a}$ & $2.7 \mathrm{a}$ & 29.1 \\
Dead material accumulation rate $\left(\mathrm{kg} \mathrm{ha}^{-1}\right.$.day DM) & $-10.2 \mathrm{~b}$ & $3.7 \mathrm{a}$ & $-4.7 \mathrm{a}$ & $-2.0 \mathrm{a}$ & 33.8 \\
Tillering $\left(\right.$ tillers $\left.\mathrm{m}^{-2}\right)$ & $241.1 \mathrm{a}$ & $254.3 \mathrm{a}$ & $257.7 \mathrm{a}$ & $237.4 \mathrm{~b}$ & 17,6 \\
\hline
\end{tabular}

Means followed by different letters differ by Fischer test $(P<0.05)$.

Negative values obtained from dead material accumulation are explained by the senescence process which occurred during the regrowth period, where senescent material present in post-grazing came off the plant and fell to the ground. This is an important means of recycling nutrients in pasture systems, where senescent material becomes a source of nutrients and organic matter in the soil. According to Dias-Filho (2007), this route of nutrient entry into the soil is more efficient than animal excretion, since it promotes better distribution and less loss of nutrients, especially for carbon and nitrogen. However, the excess of dead material reflects a large loss of efficiency in grazing systems where forage that was produced was not properly harvested, either by grazing or by cutting.

The highest tiller population density was observed in pastures lowered to $25 \mathrm{~cm}$ post-grazing height $(P<0.05)$, regardless of cultivar (Table 4$)$. This outcome may be associated with compensation between the size/number of tillers, where the number of tillers is lower in higher pastures (SBRISSIA \& SILVA, 2008). There was no difference between cultivars for this variable $(P>0.05)$. Pastures maintained stability in tiller density during the trial period, regardless of variations in rainfall. The results corroborate the study by Santana et al. (2016), where handling of Marandu palisadegrass at $25 \mathrm{~cm}$ of height was considered an appropriate management strategy as it had forage mass which was similar to the best tillering characteristics as when handled at $35 \mathrm{~cm}$.

According to Luna et al. (2016), the cultivars of the genus Brachiaria have greater stability even with a lower amount of tillers, and a suitable tissue renewal rate which are indicators of forage production and pasture sustainability.

By evaluating tiller dynamics, it was observed that the first generation of tillers was always more numerous, regardless of the cultivar or management (Figure 2), and there was a decrease in their generation during the experimental period. In both cultivars managed at $30 \mathrm{~cm}$, there was a reduction in total tillers from the second to the third evaluation. This may have occurred due to two reasons: the first is that the regrowth periods were shorter; and the second can be associated to compensation that occurs between the size and number of tillers (SBRISSIA \& SILVA, 2008), as they are constantly cut in pastures of greater height managed at $30 \mathrm{~cm}$ and could have larger and heavier tillers. 

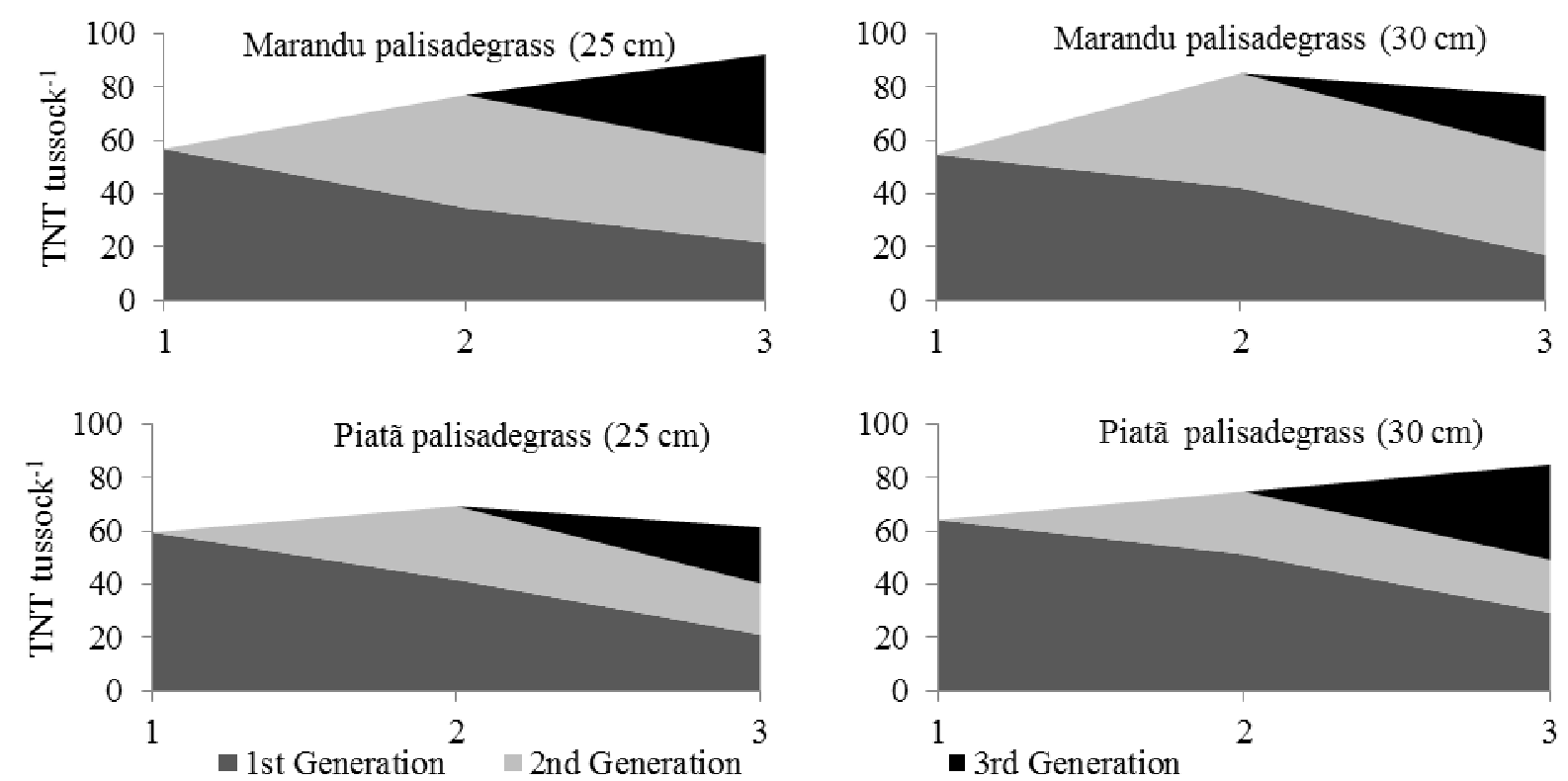

Figure 2. Tiller population dynamics (total number of tillers (TNT) tussock ${ }^{-1}$ ) in Brachiaria brizantha pastures under post-grazing canopy heights

In the third generation, the appearance of tillers was higher in pastures managed at $25 \mathrm{~cm}$ post-grazing heights when compared to those managed at $30 \mathrm{~cm}$. But the opposite happened in Marandu palisadegrass pastures, as greater tiller appearance rate was observed at the post-grazing height of $25 \mathrm{~cm}$ in relation to the height of $30 \mathrm{~cm}$. The evaluated cultivars have the same response to the environment as the same responses were obtained for similar moisture, nitrogen fertilization conditions and management goals. The greater intensity of grazing $(25 \mathrm{~cm})$ provided better light conditions for the formation of new tillers.

\section{CONCLUSION}

It was observed that 25 and $30 \mathrm{~cm}$ postgrazing heights combined with $45 \mathrm{~cm}$ pre-grazing heights do not modify the structure of Piatã and Marandu pasture cultivars in pre-grazing; however, if the goal is shorter regrowth and more grazing cycles, the indicated post-grazing height for these cultivars is $30 \mathrm{~cm}$ when grazed by livestock sheep.

\section{ACKNOWLEDGEMENTS}

To CNPq and CAPES for the financial support for the experiment development and the scholarship to the first author. Also to the group of forage studies-GEFOR (UFRN), for their support in the research.

RESUMO: Objetivou-se avaliar parâmetros produtivos e estruturais das cultivares Piatã e Marandu submetidas a duas intensidades de pastejo. O delineamento experimental foi em blocos ao acaso, com os tratamentos em arranjo fatorial 2 x 2 (Marandu e Piatã x 25 e $30 \mathrm{~cm}$ de alturas de resíduo). O método de pastejo empregado foi o de lotação intermitente. Como agentes de desfolhação foram utilizados ovinos sem padrão racial definido. A interação entre cultivar e altura não foi significativa para nenhuma das variáveis. Nos pastos manejados a $25 \mathrm{~cm}$ de altura no pós-pastejo foi observado maior período de rebrotação. A massa de forragem foi em média, 27\% maior no capim-Marandu em relação ao capim-piatã, independentemente da altura. $\mathrm{O}$ acúmulo de material morto foi maior na cultivar Marandu. Não houve diferença nas massas entre as cultivares e alturas para de lâmina foliar e colmo no pré e pós-pastejo. A maior densidade populacional de perfilhos foi observada em pastos rebaixados a $25 \mathrm{~cm}$ de altura pós-pastejo, sem diferença entre as cultivares. Na terceira geração o aparecimento de perfilhos foi superior nos pastos manejados a $25 \mathrm{~cm}$. As alturas de pós-pastejo de $25 \mathrm{e} 30 \mathrm{~cm}$ não modificam a estrutura dos pasto das cultivares de Piatã e Marandu no pré-pastejo, porém manejados a $30 \mathrm{~cm}$ é possível obter menor tempo de rebrotação.

PALAVRAS-CHAVE: Brachiaria brizantha. Composição morfológica. Manejo do pastejo. Perfilho, semiárido. 


\section{REFERENCES}

ALEXANDRINO, E.; MOSQUIM, P. R. M.; NASCIMENTO JÚNIOR, D.; VAZ, R. G. M. V.; DETMANN, E. Evolução da biomassa e do perfil da reserva orgânica durante a rebrotação da Brachiaria brizantha cv. Marandu submetida a doses de nitrogênio. Rev. Bras. Saúde Prod. Anim., Salvador, v. 9, n. 2, p. 190-200, 2008.

AZEVEDO JUNIOR, R. L.; OLIVO, C. J.; MEINERZ, G. R. M.; AGNOLIN, C. A.; DIEHL, M. S.; MORO, G.; PARRA, C. L. C.; QUATRIN, M. P.; HORST, T. Produtividade de sistemas forrageiros consorciados com amendoim forrageiro ou trevo vermelho. Ciênc. Rural, Santa Maria, v. 42, n. 11, p. 2043-2050, 2012.

BREMM, C.; SILVA, J. H. S.; ROCHA, M. G.; ELEJALDE, D. A. G.; OLIVEIRA NETO, R. A.; CONFORTIN, A. C. C. Comportamento ingestivo de ovelhas e cordeiras em pastagem de azevém-anual sob níveis crescentes de suplementação. R. Bras. Zootec., Viçosa, v. 37, p. 97-106, 2008.

http://dx.doi.org/10.1590/S1516-35982008001200004

CASAGRANDE, D. R.; RUGGIERI, A. C.; JANUSCKIEWICZ, E. R.; GOMIDE, J. A.; REIS, R. A.; VALENTE, A. L. S. Características morfogênicas e estruturais do capim-marandu manejado sob pastejo intermitente com diferentes ofertas de forragem. R. Bras. Zootec, Viçosa, v. 39, n. 10, p. 2108-2115, 2010. http://dx.doi.org/10.1590/S1516-35982010001000002

DA SILVA, S. C.; PEDREIRA, C. G. S. Princípios de ecologia aplicados ao manejo de pastagem. In: SIMPÓSIO SOBRE ECOSSISTEMAS DE PASTAGENS, 3. 1997, Jaboticabal. Anais... Jaboticabal: FUNEP, 1997. p. 1-62.

DIAS-FILHO, M. B. Degradação de pastagens: processos, causas e estratégias de recuperação. $3^{\text {a }}$. Edição. Belém: Embrapa Amazônia Oriental. 190p. 2007.

DIFANTE, G. S.; NASCIMENTO JÚNIOR, D.; SILVA, S. C.; EUCLIDES, V. P. B.; MONTAGNER, D. B.; SILVEIRA, M. C. T.; PENA, K. S. Características morfogênicas e estruturais do capim-marandu submetido a combinações de alturas e intervalos de corte. R. Bras. Zootec, Viçosa, v. 40, p. 955-963, 2011.

http://dx.doi.org/10.1590/S1516-35982011000500003

EMERENCIANO NETO, J. V.; DIFANTE, G. S.; MONTAGNER, D. B.; BEZERRA, M. G. S.; GALVÃO, R. C. P.; VASCONCELOS, R. I. G. Características estruturais do dossel e acúmulo de forragem em gramíneas tropicais, sob lotação intermitente e pastejada por ovinos. Biosci. J., Uberlândia, v. 29, n. 4, p. 962-973, 2013.

EUCLIDES, V. P. B.; MACEDO, M. C. M.; VALLE, C. B.; BARBOSA, R. A.; GONÇALVES, W. V. Produção de forragem e características da estrutura do dossel de cultivares de Brachiaria brizantha sob pastejo. Pesq. Agropec. Bras., Brasília, v. 43, n. 12, p. 1805-1812, 2008.

GOMIDE, C. A. M.; GOMIDE, J. A. Morfogênese de cultivares de Panicum maximum Jacq. R. Bras. Zootec., Viçosa, v. 29, n. 2, p. 341-348, 2000. http://dx.doi.org/10.1590/S1516-35982000000200004

HODGSON, J. Grazing management: science into practice. New York: Wiley; Burnt Mill, Harlow, Essex: Longman Scientific and Technical, 1990. 203p.

JANK, L; VALLE, C. B.; RESENDE, R. M. S. Breeding tropical forages. Crop Breed. Appl. Biotechnol, Viçosa, v. 11, p. 27-34, 2011. http://dx.doi.org/10.1590/S1984-70332011000500005

LUNA, A. A.; DIFANTE, G. S.; MONTAGNER, D. B.; EMERENCIANO NETO, J. V.; ARAUJO, I. M. M.; FERNANDES, L. S. Tillering dynamic and structural characteristics of tropical grasses under cutting management. Biosci. J., Uberlândia, v. 32, n. 4, p. 1008-1017, 2016. http://dx.doi.org/10.14393/BJv32n4a2016-32944 
PENATI, M. A.; CORS, M.; CONGIO, G. F. S.; ALMEIDA. P. C.; GOULART, R. C. D.; SHIOTA, M. M. Effects of post-grazing forage mass on a beef cattle grazing system on Tanzânia grass pastures. R. Bras. Zootec, Viçosa, v. 43, n. 6, p. 296-300, 2014. http://dx.doi.org/10.1590/S1516-35982014000600003

REGO, F.C.A.; DAMASCENO, J.C.; FUKUMOTO, N.M.; CÔRTES, C.; HOESHI, L.; MARTINS, E.N.; CECATO, U. Comportamento ingestivo de novilhos mestiços em pastagens tropicais manejadas em diferentes alturas. R. Bras. Zootec, Viçosa, v. 35, n. 4, p. 1611-1620, 2006. http://dx.doi.org/10.1590/S151635982006000600006

SANTANA, S. S., BRITO, L. F., AZENHA, M. V., OLIVEIRA, A. A., MALHEIROS, E. B., RUGGIERI, A. C.; REIS, R. A., Canopy characteristics and tillering dynamics of Marandu palisade grass pastures in the rainydry transition season. Grass Forage Sci., v. 71, n. 2, 2016. http://dx.doi.org/10.1111/gfs.12234

SALES, R. M. P.; FRIES, D. D.; PIRES, A. J. V.; BONOMO, P.; SANTANA, S. A.; SANTOS, I. S.; ROCHA, A. V.; SOBRAL, D. M. P. L. Nitrogen fertilization on the establishment of Arachis pintoi cv. Belmonte. R. Bras. Zootec, Viçosa, v. 41, n. 11, p. 2303-2308, 2012. http://dx.doi.org/10.1590/S1516-35982012001100001

SBRISSIA, A. F.; SILVA, S. C. Compensação tamanho/densidade populacional de perfilhos em pastos de capim-marandu. R. Bras. Zootec, Viçosa, v. 37, n. 1, p. 35-47, 2008. http://dx.doi.org/10.1590/S151635982008000100005

THORNTHWAITE, C. W. An approach toward a rational classification of climate. Geogr. Ver., New York, v. 38, p. 55-94, 1948. http://dx.doi.org/10.2307/210739 